KREATIF : Jurnal Ilmiah Prodi Manajemen Universitas Pamulang, Volume 8, No. 1, Juni 2020

KREATIF

Jurnal Ilmiah

Prodi Manajemen Universitas Pamulang
ISSN : $2339-0689$, E-ISSN : 2406-8616

J. KREATIF, Vol. 8, No.1, Juni 2020 (Halaman 104-123)

Tersedia Online di: http://openjournal.unpam.ac.id/index.php/kreatif

\title{
PERAN PIMPINAN DALAM PENGEMBANGAN KARAKTER ANAK BUAH UNTUK MENINGKATKAN KINERJA \\ [Studi Pada Karyawan Divisi Contract dan Procurement Bagian Non- Engineering PT Chandra Asri Petrochemical Menggunakan Analisa Myers- Birggs Type Indicator (MBTI)
}

\author{
Tutug Sri Jatmiko \\ Program Studi Manajemen Fakultas Ekonomi Universitas Pamulang \\ Email: dosen01338@unpam.ac.id
}

\begin{abstract}
ABSTRAK
Myers-Birggs Type Indicator (MBTI) merupakan alat untuk melakukan psikologi test sebagai pengukur preferensi psikologis individu dalam melihat dunia dan membuat keputusan. Dasar MBTI terletak pada jenis dan preferensi kepribadian Carl Gustav Jung, penulis Psychological Types pada tahun 1921. MBTI dikembangkan oleh Isabel Briggs Myers pada sejak 1940.

Psikologi test ini sebagai alat bantu mengukur kecerdasan individu, bakat, dan tipe kepribadian seseorang. Alat psikotes ini juga dipakai dalam rangka mengetahui karakter pribadi setiap karyawan perusahaan agar dapat ditempatkan sesuai bidangbidang yang membuat potensi karyawan tersebut maksimal. Manager NonEngineering CNP-CAP melakukan tes MBTI kepada beberapa anak buahnya untuk menganalisa sisi-sisi potensi mereka yang bisa dikembangkan guna memaksimalkan kinerja mereka.
\end{abstract}

\begin{abstract}
Myers-Birggs Type Indicator (MBTI) is a tool for conducting psychological tests as a measure of an individual's psychological preferences in seeing the world and making decisions. The basis of MBTI lies in the type and personality preferences of Carl Gustav Jung, author of Psychological Types in 1921. MBTI was developed by Isabel Briggs Myers in 1940.

This psychology test is a tool to measure a person's intelligence, talents, and personality type. This psychological test tool is also used in order to find out the personal character of each company employee so that it can be placed according to fields that make the maximum potential of the employee. The CNP-CAP NonEngineering Manager conducted MBTI tests on several of his subordinates to analyze sides of their potential that could be developed to maximize their performance.
\end{abstract}

\section{PENDAHULUAN}

Sebagai perusahaan petrokimia terbesar dan terintegrasi secara vertikal di Indonesia dengan fasilitas-fasilitasnya yang terletak di Ciwandan, Cilegon dan Puloampel, Serang di Provinsi Banten, Chandra Asri Petrochemical (CAP) merupakan pabrik petrokimia utama dan pertama yang memanfaatkan teknologi dan fasilitas pendukung canggih kelas dunia. Jantung operasi CAP adalah Lummus Naphtha Cracker yang menghasilkan Ethylene, Propylene, Mixed C4, dan Pyrolysis Gasoline (Py-Gas) berkualitas tinggi untuk Indonesia serta pasar ekspor regional. 
Selain memiliki fasilitas produksi Polyethylene dan Polypropylene terintegrasi yang menggabungkan dua teknologi kelas dunia, CAP juga merupakan pabrik Naphtha Cracker terbesar di Indonesia. Memiliki empat reaktor Unipol dengan lisensi dari Union Carbide, dima satu reaktor mampu menghasilkan resin Linear Low dan High Density Polyethylene; dan tiga reaktor lainnya mampu menghasilkan berbagai resin Polypropylene. Reaktor kelima menggunakan lisensi dari Showa Denko KK yang memiliki teknologi revolusioner Jepang dan dikenal sebagai Bimodal High-Density Polyethylene. Teknologi kelas dunia tersebut digabungkan untuk memproduksi berbagai grade resin Polyethylene yang memenuhi sebagian besar kebutuhan permintaan konsumen Polyethylene di Indonesia dan sebagian dilakukan eksport keberbagai mancanegara bersaing dengan SCG Thailand, Exxon Chemical dan Lotte Titan Korea.

CAP memiliki pembangkit listrik terpasang dengan kapasitas yang melebihi kebutuhan produksi normal sebagai sumber energi operasio guna memastikan produksi yang berkesinambungan,. CAP juga memiliki sambungan sekunder ke PLN sebagai sumber listrik cadangan. CAP didala, fasilitas produksinya juga memiliki instalasi desalinasi untuk pengolahan air yang menghasilkan air yang sangat murni untuk digunakan pada sistem pendingin, tanki penyimpanan, dan jetty.

PT Chandra Asri Petrochemical Tbk (CAP) memiliki dua (2) entitas anak perusahaan yaitu PT Styrindo Mono Indonesia (SMI) dan PT Petrokimia Butadiene Indonesia (PBI). Styrindo Mono Indonesia (SMI) adalah produsen Styrene Monomer di Indonesia satu-satunya yang melayani baik industri hilir domestik dan pasar ekspor regional seperti Malaysia, Thailand, Singapura, Filiphina, dll. Terletak di Puloampel, Serang, dan berada sekitar 40KM dari pabrik Naphtha Cracker. Pabrik SMI memproduksi Styrene Monomer dengan kapasitas 340,000MT per tahun yang dijalankan dengan sekitar 250 tenaga kerja tetap maupun kontrak. SMI memiliki dua unit pabrik Ethyl Benzene dirancang dengan lisensi dari Mobil/Badger dan teknologi-teknologi Lummus. Kedua unit Ethyl Benzene tersebut terintegrasi dengan dua unit pabrik Styrene Monomer yang direkayasa menggunakan teknologi Lummus/UOP sebagai unit penggerak utama mesin produksinya.

Entitas yang satu lagi yaitu, Petrokimia Butadiene Indonesia (PBI) merupakan pabrik pertama Butadiene di Indonesia untuk memenuhi kebutuhan pasar regional. Kapasitas produksinya adalah 100,000MT per tahun dengan bahan baku Mixed C4 yang merupakan produk turunan dari pabrik Naphtha Cracker hasil produksi CAP. Butadiene merupakan bahan baku yang digunakan di dalam produksi karet sintetis yang merupakan bahan baku utama dalam produksi ban.

Dengan jumlah pegawai lebih dari 4000 karyawan, CAP memiliki lebih dari 50 Departemen diseluruh entitasnya. Divisi Contract and Procurement (CNP) adalah salah satu divisi yang dibawahi oleh Direktur Finance. Didalam Divisi CNP ada dua bagian/seksi yaitu Bagian Engineering dan Bagian Non-Engineering. Tugas pokok dari CNP adalah mengelola penyediaan barang dan jasa kepada seluruh pengguna yang membutuhkan untuk mendukung operasi dan produksi berjalan lancar dan tidak ada kendala baik dari sisi teknis maupun non-teknis.

Divisi CNP dipimpin oleh seorang General Manager yang membawahi dua (2) Manager Seksi, yaitu, Seksi Engineering dan Seksi Non-Engineering. Dua seksi tersebut memiliki deskripsi kerja dan user yang berbeda. Secara umum dapat dipisahkan bahwa Seksi Engineering memiliki tanggungjawab untuk mendukung 
penyediaan barang dan jasa yang bersifat pada engineering/plant operasional, sehingga user dari Seksi Engineering adalah mereka yang ada dalam Divisi Pengelolaan dan Perawatan Plant atau fasilitas produksi seperti Maintenance and Technical Engineering. Sedangkan Seksi Non-Engineering memiliki deskripsi kerja untuk mendukung kebutuhan operasional secara umum diluar engineering/plant operasional seperti: Semua Divisi dibawah Direksi HRD and Corporate Affair, Divisi yang dibawah Total Quality Management, Divisi yang dibawah Finance, dll.

Seksi Non-Engineering dipimpin oleh seorang manager dengan dua (2) supervisor dan 6 staff. Dari sisi usia, tim Non-Engineering memiliki usia antara 26 - 45 tahun, sedangkan dari jenis kelamin, 3 dari 9 adalah pria sedangkan 6 diantaranya adalah perempuan.

Karakter yang dimiliki cukup variatif melihat masa kerja dan latar-belakang pendidikan mereka juga yang berbeda. Sehingga untuk mempertahankan dan meningkatkan kinerja, manajer sebagai pucuk pimpinan dalam seksi harus memiliki tips dan trik dalam proses pekerjaan serta pengelolaannya. Salah satu tips dan trik yang dilakukan adalah dengan menganalisa karakter dan kepribadian menggunakan bantuan alat analisa Myers-Birggs Type Indicator atau biasa disingkat MBTI. Harapannya dengan dilakukan analisa karakter dan kepribadian beberapa staff yang memiliki peran penting dalam tim atau sedang ada indikasi penurunan kinerja menggunakan MBTI, maka bisa diketahui sisi-sisi yang bisa dikembanhgkan dan sisi-sisi yang harus dihilangkan/dikurangi.

\section{TINJAUAN TEORITIS}

Test Indicator MBTI digunakan dengan tujuan untuk mengetahui sisi-sisi karakter dan kepribadian staff yang dianggap jadi kunci dan memiliki potensi dikembangkan lebih maksimal. MBTI dipilih oleh Penulis karena dianggap cukup sesuai dengan kebutuhan penulis dalam proses pengembangan karakter anak buah serta meningkatkan kinerja tim Non-Engineering. Disamping itu, analisa MBTI ini ditetapkan oleh CAP sebagai alat analisa resmi bagi level Manager keatas dalam proses pengembangan kinerja tim.

Istilah Myers-Birggs Type Indicator (MBTI) dalam dunia psikologi dikenal sebagai alat tes yang mengukur preferensi psikologis seseorang dalam melihat dunia dan membuat keputusan. Dasar MBTI ada pada jenis dan preferensi kepribadian milik Carl Gustav Jung, penulis Psychological Types pada tahun 1921dan dikembangkan Isabel Briggs Myers pada tahun 1940. Alat tes ini dirancang untuk mengukur kecerdasan individu responden, bakat responden, dan tipe kepribadian responden. Dengan alat tes ini dapat diketahui berbagai karakter kepribadian karyawan perusahaan untuk tujuan agar mereka dapat ditempatkan sesuai dengan bidang-bidang yang membuat potensi karyawan tersebut bekerja secara optimal [The Myers and Briggs Foundation, 2020, seperti ditulis kembali oleh Universitas Prasetya Mulya, 2018]

Kecenderungan sifat dasar manusia yang dijelaskan dalam tes MBTI memiliki 4 dimensi, yaitu:

1. Dimensi pemusatan perhatian yang biasa disebut sebagai sosok Introvert (I) vs. Ekstrovert (E)

3. Dimensi memahami informasi dari luar yang biasa disebut sebagai sosok Sensing $(\mathrm{S})$ vs. Intuition $(\mathrm{N})$ 
4. Dimensi menarik kesimpulan \& keputusan yang biasa disebut sbg sosok Thinking (T) vs. Feeling (F)

5. Dimensi pola hidup yang biasa disebut sebagai sosok Judging (J) vs. Perceiving (P)

Sedangkan type karakter kepribadian yang dirumuskan oleh MBTI kepada setiap pribadi manusia ada 16 karakter, yaitu: ENFJ, ENFP, ENTJ, ENTP, ESFJ, ESFP, ESTJ, ESTP, INFJ, INFP, INTJ, INTP, ISFJ, ISTJ, ISFP, ISTP. Dimana masing-masing karakter tersebut memiliki penjelasan yang unik terkait karakternya, ciri-cirinya, sisi yang harus dikembangkan dan sisi yang perlu diminimalisir termasuk pasangan ideal dalm bekerja dan beraktifitas atau dibeut sebagai partner alami-nya.

Penjelasan lebih detail dari setiap karakter yang sesuai dijelaskan dalam MBTI dapat dijelaskan sebagai berikut:

Karakter - ENFJ, atau lebih dikenal sebagai "The Givers" (Pemberi) \& "Teacher" (Pengajar) adalah seseorang yang memiliki sifat yang sangat peduli, memiliki perhatian, suka mendengarkan, dan responsible. Mereka memiliki penyesuaian yang bagus, memahami akan kebutuhannya, dan bisa memberikan motovasi kepada rekan kerja. ENFJ juga pintar mendorong rekan kerja untuk bertumbuh serta berkembang dalam tim. Disamping dia juga punya loyalitas yang bagsu, tidak alergi kritik dan suka mendengarkan pujian. Sifatnya yang terbuka mampu membuat dia gampang bergaul, suka membantu rekan kerja, dan memiliki semangat kepemimpinan yang bagus. Kepribadian karakter ENFJ memiliki ciri-ciri seseorang yang kreatif, imajinatif, peka, sensitive, sangat loyal.

Pada umumnya seorang ENFJ adalah orang yang punya kepedulian pada apa kata orang atau apa yang orang lain katakan dan inginkan dan cenderung melakukan sesuatu dengan memperhatikan perasaan rekan kerjanya. ENFJ juga pandai bergaul, pandai meyakinkan orang lain, sangat ramah, menyenangkan, populer dalam kelompoknya, penuh simpatik dan responsif pada kritik serta pujian. Seringkali ENFJ sangat menyukai variasi dan tantangan baru, memtutuh apresiasi dari orang lain dan butuh penerimaan kelompoknya. adalah:

Hal-hal yang perlu diperhatikan oleh seseorang yang memiliki karakter ini

1. Jangan mengorbankan diri hanya untuk menyenangkan orang lain.

2. Jangan mengukur harga diri anda dari perlakukan orang lain.

3. Jangan mudah kecewa jika rekan kerja tidak seperti yang anda inginkan.

4. Belajarlah untuk tegas dalam mengambil keputusan dan siap menghadapi kritik dan konflik.

5. Jangan terlalu bersikap keras terhadap diri sendiri.

Dalam proses pengembangan teamwork yang solid dan maksimal, seorang ENFJ disarankan untuk berpartner alami dengan INFP atau ISFP.

Karakter - ENFP adalah sosok yang juga dikenal sebagai "The Inspirers" (Penjiwa) \& "Champion" (Juara). Sebagai seseorang yang menginspirasi serta potensi tinggi menjadi juara, maka ENFP memiliki sifat yang hangat dan memiliki ansuiasme tinggi serta imaginatif. Seringkali seseorang dengan karakter ini memandang hidup sebagai sesuatu yang penuh dengan kemungkinan, dia juga memiliki kemampuan memahami hubungan antara kejadian dengan informasi dengan sangat mudah.Punya kepercayaan diri melakukan sesuatu berdasarkan pola 
yang mereka lihat, menginginkan banyak pengakuan dari orang lain, siap memberikan apresiasi dan dukungan, bersikap spontan dan flesibel, serta seringkali mengandalkan kemampuan mereka dalam improvisasi dan kefasihan lisan.

Karakter ENFP adalah karkater pemain watak yang memiliki ciri khas sebagai sosok yang ramah, hangat, energik, optimis, antusias, semangat tinggi, menyenangkan, penuh imaginatif, penuh ide, kreatif, inovatif serta pandai berkmonikasi dengan rekan kerja. Dia juga senang bersosialisasi dan membawa suasana positif. Dalam keadaan tertentu mereka yang memiliki karakter ini mudah membaca perasaan dan kebutuhan orang lain. Kadang orang disekitarnya menyebut sebagai indigo.

Mereka yang memiliki karakter ENFP dapat dikembangkan dengan memperhatikan untuk fokus, disiplin, tegas dan konsisten. Mereka juga perlu belajar untuk menghadapi konflik dan kritik, tidak lari dari permasalahan yang muncul. Lebih banyak memikirkan kebutuhan diri sendiri, jangan melupakannya karena terlalu peduli pada kebutuhan orang lain dan melupakan diri sendiri. Karena ENFP berjiwa sangat sosial, maka mereka sebaiknya jangan terlalu boros, belajar untuk mengelola keuangan sedikit demi sedikit.

Apabila memiliki rekan kerja atau anak buah yang memiliki karakter ENFP, sebaiknya pimpinan dapat mencarikan mereka partner alami yang memiliki karakter INTJ atau INFJ.

Karakter - ENTJ dapat dikenal juga dengan sebutan "The Executives" (Pelaksana) \& "Fieldmarshal" (Panglima), mereka yang memiliki karakter ini lebih banyak menikmati sebagai pelaku yang berbakat memimpin, sikapnya berterus terang, menentukan, siap memikul kepemimpinan. Cara kerja yang biasa mereka lakukan adalah dengan selalu melihat prosedur atau kebijakan yang tidak efisien dan tidak logis, mampu mengembangkan dan mengimplementasikan sistem yang luas untuk menyelesaikan masalah-masalah organisasi. Pandangannya kedepan karena menyukai rencana jangka panjang, dan penetapan tujuan yang baik. Biasanya mereka berpengetahuan luas, pembaca yang baik, senang mengembangkan pengetahuan mereka dan menyampaikannya dengan baik kepada rekan kerja. Terkadang memaksa dalam menyajikan ide-ide mereka.

Dalam bekerja ataupun beraktivitas bersama rekannya, seorang ENTJ biasa tegas, asertif, to the point, jujur terus terang, obyektif, kritis, \& punya standard tinggi. Polanya sangat mendominasi dalam kelompok, kemauannya kuat, bekerja dengan target perfeksionis dan kompetitif. Tidak takut persaingan dan tangguh dalam tantangan, disiplin, sangat menghargai komitmen, cenderung menutupi perasaan dan menyembunyikan kelemahannya. Bakatnya yang menjadi pemimpin membuat mereka yang berkarakter ENTJ berkarisma, memiliki komunikasi yang baik, serta memiliki kemampuan dalam menggerakkan orang.

Karena visinya yang kedepan, ENTJ dipenuhi dengan pencapaian target yang sempurna sehingga kelemahan meraka kurang relaks. Sulit menerima sesuatu yang kurang perfeksionis dan selalu kompetitif dengan semua orang. Hal ini bisa membuat mereka yang memiliki karakter ini cepat stress dan mudah sakit, sehingga tingkat absensinya lumayan banyak bagi yang tidak memperhatikan kesehatan. Untuk menghilangkan kondisi negatif tersebut, maka ENTJ perlu sering mengungkapkan perasaan, belajar mengelola emosi, dan jangan mudah marah. Bagaimana caranya dalam keseharian, mudah untuk menghargai dan memberikan 
apresiasi orang lain, tidak terlalu arogan dan menganggap remeh orang lain adalah aktifitas yang bisa mengurai rasa stress yang mudah menghinggapi ENTJ. Kemampuan yang baik untuk menggerakan orang sekali waktu ditujukan tidak hanya untuk pekerjaan, tetapi juga untuk tujuan lain yang rileks, misalkan nonton bersama, olahraga bersama, makan bersama dan lain-lain. Hal-hal yang perlu dikembangkan ENTJ agar karakternya tidak berkontribusi negatif dalam teamwork salah satunya adalah mencarikan partner alami seorang INTP atau ISTP.

Karakter - ENTP biasa dikenal dengan "The Visionaries" (Visioner) \& "Inventor" (Penemu), dimana sosoknya memiliki karakter yang cepat bertindak, berbakat, pendorong motivasi dalam kelompok, bersikap selalu siaga, dan suka bicara terus terang. Sosok karakter ini merupakan pribadi yang sanggup untuk memecahkan masalah yang menantang dengan cepat, dapat menganalisa kemungkinan secara strategis akan hal-hal yang dihadapi dalam tim, mampu membaca gerak dan pikiran yang ada dalam rencana orang lain, mudah jenuh dengan rutinitas semata, tidak tertarik melakukan hal yg sama berulang-ulang, lalu mencoba hal yang menarik minatnya. Karakter ENTP sangat suka membaca serta meresume apa yang telah dibacanya, tindakannya tekstual.

Dalam bekerja sosok berkarakter ENTP sangat gesit, kreatif, inovatif, cerdik, logis, baik dalam banyak hal. Mereka cenderung banyak bicara dan punya kemampuan debat yang baik, memiliki argumentasi yang baik untuk senang-senang saja tanpa merasa bersalah, tapi sikapnya fleksibel dan mudah melupakan apa yang telah dia perdebatkan. ENTP punya banyak cara untuk memecahkan masalah dan tantangan tetapi kurang konsisten karena sering lupa terhadap proses yang telah dia lakukan. Cenderung suka melakukan hal baru yang menarik hati setelah melakukan sesuatu yang lain sehingga punya keinginan kuat untuk mengembangkan diri. Hasilnya adalah karakter ENTP dalam pengalaman kerja minimal akan memiliki 3 tempat kerja yang berbeda.

Untuk meminimalisir kontribusi negatif yang dibawanya dalam tim, ENTP harus dikembangkan untuk banyak berpikir win-win solution dalam penyelesaian masalah, dihindarkan untuk terus mengembangkan rasa ingin menang sendiri, diberikan tabel cek list agar yang memaksa dia disiplin dan konsisten serta tidak mengajaknya dalam situasi perdebatan tidak penting terlalu sering.

Belajarlah untuk sedikit waspada. Seimbangkan cara panda anda aagar tidak terlalu optimis dan mengambil resiko yang tidak realistis. Terakhir karakter ENTP sebisa mungkin didorong dalam pola hubungan yang sering memberikan perhatian pada perasaan orang lain. Misalkan diwajibkan melakukan apresiasi secara tulus kepada teman sehari lima (5) kali.

Pimpinan semaksimal mungkin mencarikan partner alami ENTP dengan INFJ atau INTJ agar bisa maksimal dan engage dalam kerja tim.

Karakter - ESFJ oleh Isabel Briggs Myers disebut sebagai "The Caregiver s" (Pengasuh) \& "Provider" (Pemberi) karena sosoknya yang sangat bersahabat, bersungguh-sungguh dalam mengerjakan sesuatu, dan dapat bekerjasama. Mereka cenderung menginginkan keharmonisan dalam lingkungan mereka, bekerja dengan kebulatan tekat, senang bekerja dengan orang lain untuk menyelesaikan tugas-tugas dengan teliti, dan tepat waktu, sangat loyal kepada pimpinan maupun teman kerja yang disukai, mampu melaksanakan tugas hingga hal-hal kecil sekalipun. Dalam 
pola hubungan komunikasi kerja seorang dengan karakter ESFJ sangat memperhatikan apa yang menjadi kebutuhan orang lain dalam memperhatikan apa yang menjadi kebutuhan orang lain dalam keseharian mereka dan, mencoba untuk memenuhi itu semua. ESFJ sangat ingin dihargai untuk siapa diri mereka dan segala kontribusi mereka dilakukan.

Secara nyata dalam pergaulan keseharian, sosok ESFJ menampilkan peran yang hangat dalam komunikasi, banyak bicara kepada lawan bicara, populer diantara tim, dilahirkan untuk bekerjasama dengan terbuka, suportif kepada yang lain dan anggota kelompok yang aktig, sangat membutuhkan keseimbangan dengan lawan bicara dn baik dalam menciptakan harmoni baik kepada pimpinan maupun pada level yang sama atau dibawahnya. Rekan dalam tim orang berkarakter ESFJ akan sangat merasa nyaman karena sosok ESFJ selalu melakukan sesuatu yang manis bagi orang lain. Bekerja dengan baik dalam situasi yang mendukung dan memujinya, santai, easy going, sederhana, tidak berfikir panjang serta teliti dan rajin merawat apa yang ia miliki atau ia kerjakan.

Dibalik sosoknya yang sangat disukai rekan kerja, sosok karakter ESFJ punya karakter negatif yang suka mengorbankan diri hanya untuk menyenangkan orang lain, mengukur harga diri dari perlakuan orang lain, krisis penghargaan dan pujian orang lain. Sehingga sosok ini harus lebih banyak meminta pertimbangan orang lain dalam mengambil keputusan, belajar untuk lebih tegas, siap menerima tanggungjawab hiudo dan belajar lebih dewasa, tidak sering mengasihani diri sendiri, dan siap menghadapi kritik serta konflik. Agar menunjang suksesnya pengembangan karakter sosok ESFJ, maka pimpinan perlu mencarikan pasangan alaminya dengan ISFP atau INFP.

Karakter - ESFP merupakan sosok pribadi yang lebih disebut sebagai "The Performers" (Pemain) \& "Performer" (Pemain) dengan karakter kuat dan kental sebagai pribadi yang ramah, bersahabat, dan menerima. Sosok karakter ini sangat mencintai kehidupan, orang, dan kenyamanan material, senang sekali kerjasama dengan orang lain yang bisa dia andalkan dalam menyelesaikan sesuatu, menggunakan akal sehat dan pendekatan realistis dalam setiap pekerjaan yang dilakukan, menjadikan pekerjaan sebagai sebuah kesenangan, cukup fleksibel dan spontan dalam hubungan kerja baik dengan pimpinan maupun rekan satu level atau dibawahnya, cepat beradaptasi dengan mudah bke orang-orang dan lingkungan baru yang ditemui. ESFP punya cara belajar terbaik dengan selalu mencoba keterampilan baru bersama orang lain.

Pribadi ESFP merupakan sosok berkarakter yang mudah membantu, mudah diajak kerjasama, mudah berteman, bersahabat, sangat sosial, ramah, hangat, \& menyenangkan. Mereka juga selalu menampilkan optimisme, ceria dalam bekerja, sangat antusias, menyenangkan buat rekan satu tim dan lawan kerja, penghibur yang terkenal, suka menjadi perhatian dalam lingkungan aktifitas. Interpersonal skill mereka sangat baik, murah hati, mudah simpatik serta mampu mengenali perasaan orang lain. Suka menghindari dan menjaga keharmonisan suatu hubungan, mengetahui apa yang terjadi disekelilingnya dan ikut serta dalam kegiatan tersebut, serta sangat baik dalam keadaan yang membutuhkan common sense, tindakan cepat dan keterampilan praktis..

Proses pengembangan karakter ESFP yang harus dipahami oleh pimpinan adalah dengan memotivasi mereka untuk tidak biasa terburu-buru dalam 
pengambilan keputusan. Memberikan mereka media untuk belajar lebih fokus dan tidak mudah berubah-ubah dalam tindakan maupun keputusan, terutama untuk hal yang penting. ESFP juga perlu disadarkan untuk tidak berusaha selalu menyenangkan semua orang dan begitu pula sebaliknya, tidak mengukur semua hal dengan materi, serta meminimalisir kecenderungan materialistis dan pergaulan. Mereka perlu diajarkan untuk siap dan mampu menghadapi kritik dan konflik dalam kelompok atau tim serta tidak lari dari konflik tersebut sampai selesai. Agar hal-hal yang negatif tersebut mampu dikendalikan dan hal yang positive mampu dikembangkan, maka ESFP perlu dicarikan partner alami seseorang yang berkarakter pribadi ISTJ atau ISFJ

Karakter - ESTJ disebut juga sebagai "The Guardians" (Pelindung) \& "Supervisor" (Pengawas) yang memiliki kepribadian yang praktis, realistis, berpegang pada fakta dalam setiap tindakannya. Mereka cenderung sangat tegas dalam tim, fast implemented dalam keputusanyang dibuat. Untuk menyelesaikan sesuatu mereka mampu mengikuti ritme kerja agar tidak stress, terfokus untuk mendapatkan hasil dengan cara yang memungkinkan dan paling efisien, selalu menjaga detail rutinitas. Karakter ESTJ punya kejelasan standart logika dalam tindakan pengambilan keputusan, dan secara sistematis menuntun mereka dan orang-orang lain untuk menggunakan standart logika yang dia bangun. Terkadang mereka suka memaksa agar rencana mereka dapat terimplementasikan.

Dalam membangun karakter pribadi ESTJ, pimpinan perlu mengetahui lebih dahulu ciri-ciri pribadi mereka suka terhadap sesuatu yang praktis, realistis, berpegang pada fakta, dengan dorongan alamiah untuk bisnis dan mekanistis. ESTJ juga sosok yang sistematis, procedural dan terencana dalam setiap target yang dia catatkan. Mereka sangat disiplin, on time dan pekerja keras. Tetapi memiliki sifat yang cukup konservatif dan cenderung kaku. ESTJ juga tidak tertarik pada subject yang tidak berguna baginya tapi dapat menyesuaikan diri jika diperlukan. Senang mengorganisir rekan-rekan dalam kantor, mampu menjadi administrator yang baik jika mereka ingat untuk memperhatikan perasaan dan perspektif orang lain.

Untuk menjadikan seorang yang berkarakter ESTJ maksimal dalam kinerjanya, maka pimpinan dapat melakukan pengembangan pada sisi-sisi karakternya seperti mengurangi keinginan untuk mengontrol dan memaksa orang lain, belajar mengontrol emosi dan amarah, mau dan mampu untuk instropeksi diri dan meluangkan waktu sejenak untuk merenungi hal-hal yang telah dilakukan dalam pekerjaan sebelumnya, belajar untuk lebih sabar dan low profile kepada tim dan pimpinan, belajar untuk mau dan mampu memahami orang lain. Partner kerja alami yang perlu dimasukan dalam tim ESTJ adalah sosok pribadi yang memiliki karakter INTP dan ISTP.

Karakter - ESTP memiliki sebutan sebagai "The Doers" (Pelaku) \& "Promoter" (Promotor), dimana sosok karakter pribadi tersebut adalah sosok yang sangat fleksibel dalam bertindak dan toleran, mereka mengambil pendekatan praktis yang berfokus pada hasil yang langsung, tidak mengutamakan teori dan penjelasan konseptual karena sangat membosankan bagi mereka, tindakan mereka sangat energik dalam memecahkan masalah, fokus pada dimana mereka saat ini, dan sekarang, bersifat spontan dalam tindakan, menikmati saat-saat dimana mereka bisa 
aktif berinteraksi dengan orang lain serta menikmati kenyamanan material dan gaya.

Karakter ESTP memiliki pribadi yang spontan, aktif, enerjik, cekatan, cepat, sigap, antusias, menyenangkan dan penuh variasi. Mereka juga sangat komunikatif, asertif, bicara pada pokok masalah saja, terbuka dan terus terang, memiliki karisma, dan punya interpersonal skill yang baik.

Jika ada masalah dalam kelompok, mereka sangat baik dalam melakukan pemecahan masalah langsung di tempat karena mereka memiliki kemampuan yang baik menghadapi masalah, konflik dan kritik, tidak khawatir, menikmati apapun yang terjadi. Sosok ESTP juga memiliki kecenderungan menyukai yang mekanistis, kegiatan bersama dan olahrga, mudah beradaptasi, toleran, pada umumnya konservatif tentang nilai-nilai. Mereka tidak suka penjelasan yang panjang dan berbelit, paling baik dalam hal-hal yang nyata.

Untuk mengembangkan seseorang yang berkarakter kepribadian ESTP agar kinerjanya maksimal, pimpinan bisa mengarahkannya agar mau dan mampu belajar memahami perasaan dan pemikiran orang lain terutama saat bicara dengan mereka, belajar untuk sabar, menikmati setiap proses yang dilakukan, memberikan task force yang berorientasi pada proses dengan maksud untuk menunjukan bahwa tidak semua hal bisa dicapai dengan cepat. Sesekali diberikan waktu cukup buat ESTP untuk merenung dan merencanakan sesuatu terkait penyelesaian pekerjaan kedepan, diminta untuk mencatat pengamatan-pengamatan dengan detailnya, dan terakhir memberikan partner alami kepada ESTP dengan sosok pribadi yang berkarakter ISFJ atau ISTJ

Karakter - INFJ merupakan sosok yang dikenal sebagai "The Protectors" (Pelindung) \& "Counselor" (Penasihat), dimana sosok ini memiliki karakter kepribadian yang suka sekali mencari makna dan hubungannya dengan ide-ide, hubungan sosial, dan pekerjaan. Mereka juga selalu ingin memahami tentang pola pikir orang lain, suka belajar tentang apa yang bisa memotivasi seseorang dalam kehidupan, sosok yang bersungguh-sungguh dan berkomitmen dengan apa yang mereka kerjakan, serta memiliki misi yang jelas tentang bagaimana cara terbaik untuk melayani kepentingan semuanya, terorganisir, dan tegas dalam melaksanakan visi.

Karakter sosok INFJ sangat dinanti dalam kelompoknya karena memiliki perhatian yang baik tanpa melihat status, suka berempati, sangat sensitif \& berkomitmen terhadap sebuah hubungan. Mereka juga sosok yang sukses karena ketekunannya, originalitasnya dan keinginannya yang kuat untuk melakukan apa saja yang diperlukan termasuk memberikan yang terbaik dalam pekerjaan mereka. Jadi mereka dijadikan contoh dan diikuti oleh banyak orang. Meskipun begitu sosok ini adalah pribadi yang sangat idealis, perfeksionist, memegang teguh prinsip, visioner, penuh dengan ide, kreatif, suka merenung dan menginspirasi. Biasanya mereka didalam kelompoknya diikuti dan dihormati karena kejelasan visi serta dedikasi pada hal-hal yang baik.

Jika pimpinan memiliki anak buah atau kita memiliki pimpinan INFJ, maka kita perlu mengembangkan mereka dengan cara memberikan saran membuka pikiran mereka agar mampu menyeimbangkan cara pandang mereka akan realita dan harapan. Ajak mereka untuk ytidak selalu melihat sisi negatif \& resiko orang lain atau pekerjaan yang akan dilakukan, tapi juga mau dan mampu melihat sisi 
positif dan peluangnya. Ajak sosok INFJ untuk lebih bersabar, tidak mudah marah dan menyalahkan orang lain atau situasi yang terjadi, lebih rileks dalam segala situasi dan tidak terus menerus berfikir atau menyelesaikan tanggungjawab saja. Carikan sosok pribadi INFJ dengan pasangan alami ESFP atau ESTP agar bisa maksimal dalam kerja tim dan berkembang karakter positifnya.

Karakter - INFP dikenal juga sebagai "The Idealist" (Idealis) \& "Healer" (Penyembuh), sosok pribadi dengan karakter INFP ini memiliki idealisme yang sangat tinggi, setia pada prinsip yang digenggam serta orang-orang yang penting bagi mereka. Sikapnya selalu memilih pada pilihan ingin kehidupan yang selaras dengan prinsip yang mereka miliki, banyak ingin tahu, mudah untuk melihat kemungkinan. Bisa menjadi pemicu untuk memulai ide-ide. Mereka juga punya keinginan untuk berusaha memahami orang lain, dan membantu mereka untuk mencapai potensi mereka, mudah beradaptasi, fleksibel, dan mudah menerima, kecuali jika itu bertentangan dengan prinsip-prinsip mereka.

Karakter INFP adalah sosok pribadi yang sangat perhatian dan peka dengan perasaan orang lain, penuh dengan antusiasme dan kesetiaan, tapi biasanya hanya untuk orang dekat. Sikap mereka peduli pada banyak hal, cenderung mengambil terlalu banyak dan menyelesaikan pekerjaan sebagian, memiliki kecenderungan idelais dan perfeksionis terhadap pekerjaan serta erpikir win-win solution, mempercayai dan mengoptimalkan orang lain.

Pimpinan yang ingin mengembangkan sosok pribadi INFP bisa memberikan sisi-sisi pengembangan sebagai berikut:

a. Memotivasi mereka untuk belajar menghadapi kritik.

b. Membangun sosok INFP untuk tidak ragu bertanya dan minta saran kepada orang lain.

c. Membangun sosok INFP untuk bersikap tegas, selalu berperasaan dan menyenangkan orang dengan tindakan baik, serta membawa pemikiran mereka bahwa bertindak baik itu berbeda dengan bertindak benar.

d. Memotivasi INFP untuk tidak terlalu menyalahkan diri dan bersikap terlalu keras pada dirinya sendiri. Memberikan pemahaman pada mereka bahwa kegagalan adalah hal biasa dan semua orang penah mengalami kegagalan.

e. Mencarikan partner alami ENFJ atau ESFJ kepada sosok INFP.

Karakter - INTJ terkenal dengan sebutan "The Scientists" (Ahli Keilmuan) \& "Mastermind" (Pengatur), mereka adalah sosok yang memiliki pemikiran orisinal dan motivasi yang sangat kuat untuk menerapkan idenya hingga mencapai tujuan. Tindakannya cepat dalam melihat pola peristiwa yang terjadi disekitar mereka, serta mampu menyusunnya dalam perspektif jangka panjang yang detail dan jelas. Sosok INTJ ketika hendak melakukan sesuatu akan mengorganisir lalu segera melaksanakannya. Sifatnya banyak skeptis tetapi karakternya mandiri, memiliki standar kompetensi dan kinerja yang tinggi untuk diri mereka sendiri maupun orang lain.

INTJ merupakan sosok yang penuh dengan visi, punya perencanaan praktis dan biasanya memiliki ide-ide original serta dorongan kuat untuk mencapainya. Mereka tergolong pribadi yang mandiri dan percaya diri, punya kemampuan analisa yang bagus serta menyederhanakan sesuatu yang rumit dan abstrak menjadi sesuatu yang praktis, mudah dipahami dan dipraktekan, sikapnya 
skeptis, kitis, logis, menentukan (determinatif) dan kadang keras kepala. INTJ apabila punya keingian untuk berkembang sangat kuat dan selalu ingin lebih maju dari orang lain, sehingga kritikan dan konflik tidak masalah buat mereka.

Saran dari pengembangan yang harus dilakukan oleh pimpinan kepada INTJ adalah sebagai berikut:

a. INTJ harus diberikan motivasi untuk mampu dan mau mengungkapkan emosi \& perasaannya

b. Sosok INTJ perlu dikembangkan untuk lebih terbuka pada dunia luar, perbanyak bergaul, perbanyak belajar dan membaca, perbanyak mengunjungi tempat-tempat menarik,eksplorasi hal baru dan perluas wawasan.

c. Karena karakter INTJ yang penuh ide, penuh percaya diri dan kuat memegang prinsip, maka sosok ini harus diberikan pemahaman agar bisa menghindari perdebatan tidak penting.

d. Karakter pribadi INTJ juga perlu diajak untuk berempati, memberi perhatian dan lebih peka terhadap orang lain.

e. Yang lebih penting lagi agar INTJ tidak menjadi troublemaker di tim, maka dia harus dicarikan partner alami yang cocok yaitu ENFP atau ENTP

Karakter - INTP lebih dikenal sebagai seseorang dengan sebutan "The Thinkers" (Pemikir) \& "Architect" (Arsitek). Karakter Pemikir dan Arsitek yang dimiliki INTP memberikan gambaran penjelasan singkat tentang mereka yang berkepribadian suka berusaha membangun penjelasan yang masuk akal untuk segala sesuatu yang menarik bagi mereka. Pola pikirnya teoritis dan abstrak, lebih suka tertarik dengan ide-ide daripada interaksi sosial. Sangat tenang, cerdas, fleksibel, dan mudah beradaptasi dalam pergaulan. INTP mempunyai kemampuan yang tidak biasa untuk fokus dan mendalami pemecahan masalah pada bidang yang menjadi minat mereka, cenderung skeptis, terkadang bisa kritis, dan selalu berpkir analistis.

Pribadi seorang INTP dalam karakter mereka memiliki ciri khas sangat mengharagai pengetahuan dan intelektualitas. Suka menikmati hal-hal teoritis dan ilmiah, sangat senang memecahkan masalah dengan logika dan analisa. Tapi mereka cenderung diam dan menahan dirinya dalam pergaulan, lebih menyukai bekerja sendiri dibandingkan bekerja secara kelompok dalam tim, tetapi punya sifat kecenderungan skeptis, kritis, mudah mencurigai dan pesimis. Mereka tidak suka memimpin dan bisa menjadi pengikut yang tidak banyak melakukan tuntutan. Punya kecenderungan kejelasan minat membutuhkan karir dimana dimana minatnya bisa berkembang dan bermanfaat. Jika menemukan sesuatu yang menarik minatnya, dia akan sangat serius dan antusias menenkuninya. Sosok yang loyal dan pegang komitmen.

Pemimpin yang memiliki anak buah atau anggota tim dengan karakter INTP ini memiliki keuntungan namun juga tidak sedikit dibikin pusing karena karakternya yang cenderung tertutup dan bekerja sendiri, sehingga pimpinan dituntut untuk mampu mengembangkan mereka untuk mau dan mampu belajar membangun hubungan dengan orang sekitarnya. Memotivasi mereka untuk berempati, aktif mendengarkan, memberikan perhatian dan bertukar pendapat. Mengajak mereka untuk lebih relaks, tidak terlalu banyak berfikir, lebih bisa menikmati hidup tanpa harus bertanya mengapa dan bagaimana. Pimpinan harus 
mampu memberikan stimulus serta motivasi kepada sosok INTP agar bisa menemukan ide-ide, merencanakan dan mewujudkannya tanpa harus terlalu sering berganti ide tetapi tidak satupun yang terwujud. Lebih penting lagi, pimpinan harus bisa mencarikan pasangan partner alami kepada INTP agar bisa lebih kolaboratif dalam bekerja serta bisa engage dalam tim. Partner alami yang cocok dengan INTP adalah ENTJ atau ESTJ.

Karakter - ISFJ dalam MBTI dikenalkan sebagai sosok yang disebut sebagai "The Nurturers" (Pengasuh) \& "Protector" (Pelindung), sesuai dengan sebutan kepadanya, maka karakter pribadi ISFJ dapat diberikan penjelasan singkat sebagai sosok yang tenang sekali, ramah-tamah, memiliki tanggungjawab, dan sangat teliti. Memiliki komitmen dan sungguh-sungguh dalam memenuhi tanggungjawab kewajibannya kepada pimpinan maupun kepada kelompok. Sosok ISFJ memiliki sifat yang cermat, telaten, akurat, loyalitas yang tinggi, baik hati kepada semua, penuh dengan perhatian dan selalu mengingat secara spesifik tentang orang-orng yang penting bagi mereka, sangat peduli dengan perasaan orang lain. Mereka juga suka berupaya untuk menciptakan lingkungan yang tertib dan harmonis di tempat kerja maupun dirumah.

Pribadi ISFJ didalam kelompok dapat dilihat dari sikap kesehariannya yang penuh pertimbangan dalam bersikap, penuh hati-hati dalam keseharian untuk menghadapi pekerjaan, pekerjaannya dikerjakan dengan ketelitian dan keakuratan yang baik, sangat serius menghadapi pekerjaan tetapi tetap tenang, stabil namun sensitif dalam sikapnya. Mereka penampilannya ramah, penuh perhatian pada perasaan rekan dan kebutuhan mereka, serta kooperatif, pendengar yang baik. Sosok ISFJ memiliki kemampuan mengorganisasi, detail, teliti, sangat bertanggungjawab dan sangat bisa diandalkan.

Pimpinan dapat mengembangkan karakter ISFJ dengan jalan mengajaknya untuk mau dan mampu mlihat segala sesuatu yang dihadapi lebih dalam, lebih antusias, \& lebih semangat. Mereka juga harus dimotivasi agar mampu dan mau mengatakan tidak jika perlu, sadar tidak harus menyenangkan semua orang agar tidak dianggap plin plan, memberikan arahan agar mereka tidak terjebak zona nyaman dan rutinitas, suka mencoba hal baru dan mengajaknya dalam suasana kesadaran bahwa masih banyak hal menyenangkan yang mungkin belum pernah mereka hadapi dan mereka coba dengan jalan memberikan mereka tugas-tugas baru yang cenderung memunculkan ide baru. ISFJ perlu dicarikan partner alaminya yaitu ESFP atau ESTP agar lebih bisa mewarnai kinerja mereka tidak monoton dan tidak bervariatif.

Karakter - ISFP memiliki sebutan dan julukan sebagai "The Artist" (Seniman) \& "Composer" (Pengarang), pribadi ini memiliki karakter pribadi yang tenang, sangat ramah, berperasaan sensitif, tapi sangat baik hati. Mereka sangat menikmati apa yang sedang terjadi dan apa yang sedang dikerjakan, apa yang terjadi di sekitar mereka. Cara kerjanya sangat menginginkan ruang mereka sendiri dan bekerja dalam rentang waktu mereka sendiri. Mempunyai loyalitas yang tinggi kepada tim dan pimpinan dan berkomitmen untuk prinsip yang mereka genggam serta orangorang yang penting bagi diri mereka. Pribadi ISFP tidak menyukai perselisihan dan konflik, tidak suka memaksakan pendapat atau prinsipnya kepada orang lain atau rekan kerja. Cenderung mengambil posisi nyaman dan aman dalam bekerja. 
Untuk mengetahui bahwa seseorang disekitar kita memiliki karakter ISFP, selain dengan melakukan tes survey MBTI, kita juga bisa melihat dari cici-ciri mereka yang berpikir sederhana, praktis, fleksibel, sensitif, ramah, tidak menonjolkan diri, rendah hati pada kemampuannya. Dalam keseharian pergaulan cenderung menghindari konflik dengan teman maupun pimpinan maupun bawahan, tidak memaksakan pendapat atau nilai-nilainya pada orang lain. Biasanya karakter ISFP tidak ingin memimpin tetapi menjadi pengikut dan pelaksana setia, seringkali santai menyelesaikan pekerjaan, karena sangat menikmati apa yang sedang terjadi. Mereka juga sangat memberikan perhatian lebih banyak melalui tindakan dibandingkan dengan kata-kata.

Saran pengembangan yang bisa dilakukan pimpinan untuk anak buah atau anggota tim yang memiliki karakter ISFP adalah dengan memberikan motivasi kepada mereka agar tidak takut pada penolakan dan konflik, memberikan kesadaran bahwa mereka tidak perlu menyenangkan semua orang. ISFP juga perlu diajak untuk memikirkan dampak jangka panjang dari keputusan-keputusannya yang kecil yang mereka lakukan. Mengajak mereka untuk mengembangkan sisi kreatifitas dan seni dalam diri mereka serta mengajak mereka untuk lebih terbuka dan mengekspresikan perasaan. Akhirnya lebih penting lagi adalah menempatkan mereka dalam kelompok yang berpasangan dengan partner alami mereka yaitu ESFJ atau ENFJ.

Karakter - ISTJ diberikan sebutan sebagai "The Duty Fulfillers" (Pekerja Keras) \& "Inspector" (Pengawas) dalam kelompok karakter MBTI. Mereka dijelaskan sebagai pribadi yang memiliki karakter yang tenang, memiliki keseriusan, teliti dan handal bekerja dalam meraih sukses. ISTJ berpkir sangat praktis, memiliki fact oriented, realistis, dan responsible. Seringkali mereka memutuskan apa yang perlu dilakukan dengan logika, serta bekerja dengan ketekunan pada satu hal tanpa memperdulikan gangguan dari rekan kerja. Mereka merasa sangat senang dan menikmati segala sesuatu yang tertib dan teratur pada pekerjaan yang dikerjakan, kondisi rumahnya, serta kondisi kehidupannya. Peran ISTJ biasanya memegang nilai komitmen dan loyalitas dengan kuat. Maka tidak heran jika pimpinan sangat mencari anak buah dengan karakter ini.

Untuk mencari tim atau anak buah ISTJ, pimpinan harus menemukan ciriciri ISTJ sebagai pribadi yang serius, tenang, stabil dan damai, senang pada fakta yang terjadi, main logika, objektif, praktis dan realistis. Mereka bekerja secara task oriented, memiliki ketekunan, memiliki keteraturan, suka menepati janjinya, dapat diandalkan dan bertanggungjawab. Dalam pergaulan mereka sebagai pendengar yang sangat baik, setia pada rekan kerja, hanya mau berbagi dengan orang yang dekat. Mereka juga memegang aturan, standar prosedur dengan teguh dalam menjalankan pekerjaan.

Meskipun sosok karakter ISTJ cukup dicari oleh seorang pimpinan, namun pimpinan juga harus paham bagaimana mengembangkan karakter mereka agar maksimal kinerja dan kontribusi mereka didalam tim kerja. Untuk itu pimpinan dapat memperhatikan tips pengembangan karakter ISTJ sebagai berikut:

1. Memotivasi ISTJ untuk mau dan mampu belajar memahami perasaan \& kebutuhan orang lain. 
2. Memberikan pengertian kepada mereka untuk mengurangi keinginan untuk mengendalikan orang lain atau mengontrol orang lain guna menegakkan aturan yang ada.

3. Membuka cara pandang mereka untuk lebih banyak melihat sisi-sisi positif pada rekan kerja atau hal lainnya.

4. Memberikan pemahaman dan tugas-tugas baru untuk membuka cara pandang mereka terhadap perubahan.

5. Memberikan pasangan partner alami kepada mereka orang-orang yang memiliki karakter kepribadian ESFP atau ESTP

Karakter - ISTP disebut sebagai "The Mechanics" (Mekanik) \& "Crafter" (Pengrajin). Sosok ini dapat digambarkan sebagai sosok pribadi yang memiliki karakter dengan sikap toleran yang cukup tinggi, memiliki fleksibelitas dalam bekerja, pengamat yang sangat tenag sampai masalahnya nampak, mampu bertindak cepat dalam pekerjaan untuk menemukan solusi yang terbaik. Pola pikirnya suka melakukan analisa apa yang membuat sesuatu bekerja dengan baik, dan mampu dengan segera menemukan berbagai data untuk mengisolasi inti dari masalah tersebut. ISTP memiliki ketertarikan kepada sebab-akibat, mengolah datanya dan faktanya menggunakan prinsip yang masuk akal serta efisien.

Cara menemukan sosok ISTP yaitu dengan melihat ciri-ciri mereka yang tenang dalam sikapnya, pendiam, agak kaku, cenderung dingin, sangat berhati-hati, dan penuh pertimbangan. Dalam mengungkapkan pendapat mereka berpegang pada sesuatu yang logis, rasional, kritis, obyektif, dan mampu mengesampingkan perasaan. Mereka juga menunjukan kemampuan dalam menghadapi perubahan yang terjadi serta mendadak dengan cepat dan tenang, punya kepercayaan diri yang bagus, bersikap tegas dan mampu sekali dalam menghadapi perbedaan mauoun kritikan, punya kemampuan melakukan analisa, mengorganisir dan memberikan delegasi. ISTP adalah sosok yang berpikir problem solver yang baik terutama untuk masalah teknis dan dalam keadaan yang mendesak.

Jika pimpinan menemukan sosok berkarakter ISTP, maka pimpinan bisa mengembangkan sisi positif karakter mereka dengan mengajak mereka melakukan observasi kehidupan sosial disekitar lingkungan kerja tentang apa yang membuat orang marah, cinta, senang, termotivasi, kemudian meminta ISTP untuk menerapkan hal tersebut pada hubungan kerjanya. Memotivasi mereka untuk belajar mengenali perasaan sendiri dan mengekspresikannya kepada lingkungan pekerjaan dengan cara memberikan kesempatan lebih kepada ISTP untuk tampil, presentasi, memimpin rapat, dll. Memberikan pemahaman kepada ISTP untuk mau dan mampu menjadi lebih terbuka, keluar dari zona yg nyaman, mengeksplorasi keadaan dan ide baru, dan mau berdiskusi dengan rekan kerja. Membuka cara pandang mereka agar tidak terbiasa mencari kesalahan rekan kerja atau orang lain hanya untuk pembenaran atau menyelesaikan masalahnya. Serta mengarahkan ISTP untuk tidak suka me nyimpan informasi yang dimiliki yang harusnya dibagikan dengan rekan kerja dan mengajak mereka belajar mempercayakan tanggungjawabnya kepada orang lain. Terakhir, tugas pimpinan adalah mencarikan pasangan partner alami mereka dalam tim yaitu sosok yang memiliki karakter ESTJ atau ENTJ 


\section{METODE ANALISA}

Metode analisa yang digunakan menggunakan sistem survey melalui kuesioner pilihan ganda (Tabel: 1). Responden sudah dipilih dengan kriteria sedang memiliki kinerja yang sedang menurun dan memiliki pekerjaan penting dalam mendukung operasi. Dari kriteria tersebut terpilih 3 (tiga) orang yang terdiri 2 (dua) perempuan dan 1 (satu) laki-laki.

Hasil pengisian kuesioner akan dianalisa sesuai dengan indikator yang telah dijelaskan dalam MBTI dengan menghasilkan saran pengembangan dan peningkatan karakter/kepribadian responden serta siapa saja yang bisa menjadi parner alami/positif mereka guna meningkatkan kinerja mereka. Detail isian survey MBTI dapat dilihat pada Lampiran Tabel -1 .

\section{HASIL DAN PEMBAHASAN}

Responden survey terdiri dari tiga (3) staff yaitu: Ria Satria, Cucu Sukmaniah dan Ella Iryani. Dimana ketiga responden memiliki background jabatan maupun pendidikan yang berbeda. Ria Satria sebagai Supervisor dari dua responden lainnya memiliki background pendidikan Diploma dengan pengalaman kerja di CAP selama 25 Tahun. Sedangkan Cucu Sukmaniah dan Ella Iryani memiliki latar belakang pendidikan Sekolah Menengah Atas dan telah bekerja di CAP selama 20 dan 23 Tahun.

Sebagai satu tim, maka Ria Satria dituntut untuk memahami dan mampu mengelola dua anak buahnya bertahan pada prestasi kinerja tertentu dan jika memungkinkan mampu menaikkan kinerjanya. Guna mengetahui karakter dan pribadi masing-masing, peneliti memberikan daftar isian dari MBTI untuk diisi oleh ketiganya, dengan hasil sebagai berikut:

\begin{tabular}{|c|c|c|}
\hline No & Nama Responden & Hasil MBTI \\
\hline 1 & Ria Satria & ENFJ \\
\hline 2 & Cucu Sukmaniah & ENFP \\
\hline 3 & Ella Iryani & ESFP \\
\hline
\end{tabular}

\section{HASIL:}

Hasil MBTI Ria Satria adalah ENFJ, dimana seorang ENFJ memiliki sifat karakter yang hangat, sangat empati, sebagai pendengar yang sangat baik, serta bertanggungjawab. Sosoknya mampu menyesuaikan diri dengan emosi, kebutuhan, dan motivasi dari orang lain disekitarnya. Mereka mampu melihat sisi potensi pada setiap orangdan ingin membantu mereka mencapai potensinya. Sikap kerjanya mampu pendorong orang lain untuk pertumbuhan individu dan kelompok. Memiliki sikap yang loyal, mau mendengarkan pujian ataupun kritik, sangat suka bergaul, senang memudahkan orang lain, dan mampu menghadirkan sikap kepemimpinan yang bersemangat.

Ciri-ciri seoarang ENFJ adalah sosok yang kreatif, imajinatif, peka, sensitive, loyal. Secara umum karakter mereka sangat peduli pada apa kata orang atau apa yang orang lain inginkan dan cenderung senang memperhatikan perasaan orang lain. Mereka juga pandai bergaul dalam kelompok, sangat meyakinkan dalam komunikasi, sangat ramah, menyenangkan, punya popularitas, bersikap simpatik. Sikapnya cukup responsif pada kritik dan pujian, suka dengan variasi pola kerja dan 
tantangan baru, dan membutuhkan apresiasi dan penerimaan dari anggota kelompoknya.

ENFJ dapat dikembangkan agar memiliki kinerja yang lebih baik lagi dengan mengajak mereka untuk tidak sering mengorbankan diri mreka hanya untuk menyenangkan orang lain. Memberikan motivasi agar perlakuan orang lain sebagai tolak ukur harga dirinya. Memberikan pengertian kepada ENFJ untuk tidak mudah kecewa jika orang lain/anak buah tidak seperti yang diharapkan. Karakter ENFJ harus dimotivasi lebih tegas dalam pengambilan keputusan. Pimpinan juga memotivasi ENFJ agar siap menghadapi kritikan serta siap menghadapi konflik didalam pekerjaan. Sebagai hal terakhir, pimpinan harus mencarikan partner alami ENFJ yaitu mereka yang memiliki karakter INFP atau ISFP, dimana jika ENFJ bertemu dengan salah satu dari partner alami tersebut maka akan memunculkan motivasi positif yang mampu meningkatkan kinerja.

Hasil MBTI Cucu Sukmaniah adalah ENFP, dimana seorang ENFP adalah sosok yang hangat, memiliki antusiasme dan imaginatif yang tinggi. Mereka juga suka melihat pekerjaan sebagai sesuatu yang penuh kemungkinan. Mereka dengan sangat mudah memahami hubungan antara kejadian dan informasi, ENFP juga memiliki kepercayaan diri yang tinggi untuk melakukan sesuatu berdasarkan pola pekerjaan yang mereka lihat, pengakuan dari orang lain sangat mereka butuhkan, mereka juga siap memberikan apresiasi serta dukungan, terbuka, spontan dan fleksibel dalam bertindak, seringkali mengandalkan kemampuan dalam berimprovisasi dan kefasihan lisan untuk menyelesaikan masalah dalam pekerjaan.

Responden adalah sosok yang ramah, penuh kehangatan, memiliki sikap enerjik, sangat optimis dalam cara pandang, antusias terhadap rekan kerja dan pekerjaan yang dikerjakan, memiliki semangat tinggi, serta menyenangkan bagi lawan kerja. Pola pikrnya sangat imaginatif, idenya banyak, sangat kreatif dan inovatif. Disamping itu responden juga pandai bersosialisasi, senang berkomunikasi \& mampu membawa suasana positif dilingkungan kerja.

Pimpinan dalam melakukan pengembangan untuk ENFP mengajaknya untuk mau dan mampu lebih fokus dalam pekerjaan, bertindak disiplin, tegas dan konsisten, Pimpinan juga mengajaknya untuk siap menghadapi konflik dan kritik dengan menciptakan peta konflik dalam tim, termasuk memotivasi responden untuk lebih sering memikirkan kebutuhan diri sendiri agar tidak bersikap terlalu peduli pada kebutuhan orang lain dengan mengorbankan diri-sendiri. Hal terakhir yang dilakukan pimpinan adalah memberikan pasangan partner alami untuk ENFP yaitu karyawan lain dalam tim yang memiliki karakter pribadi INTJ atau INFJ. Hasilnya ketika bekerja bersama dengan INTJ dan INFP, responden mendapatkan kesenangan dan motivasi yang luar biasa disebabkan oleh partner yang idealis, setia, visioner dan suka mendengar.

Hasil MBTI Ella Iryani adalah ESFP, dimana seorang ESFP adalah seorang yang penuh keramah-tamahan, sangat bersahabat, dan suka menerima kondisi yang terjadi. Sosok ESFP juga mencintai rekan kerjanya, orang disekitarnya, dan senang terhadap kenyamanan materi. Mereka senang bekerja dengan orang lain dalam menyelesaikan pekerjaannya, mampu menggunakan akal sehat dan pendekatan realistis dalam pekerjaan, serta menjadikan pekerjaan sebagai sebuah kesenangan sehari-hari. Responden juga sosok yang fleksibel, memiliki spontanitas, mudah beradaptasi dengan rekan kerjanya serta orang-orang terkait dilingkungan baru. 
ESFP akan berkembang cepat dan baik dengan mencoba keterampilan baru bersama orang lain.

Responden sebagai ESFP adalah sosok yang outgoing, suka membantu, sangat mudah berteman, bersahabat dalam kelompok, memiliki jiwa sosial yang tinggi, sangat ramah dan penuh kehangatan, pribadi menyenangkan dan ;penuh optimisme, penuh keceriaan, sangat antusias dalam bekerja, menyenangkan, suka menghibur rekan kerja, suka diperhatikan dan memiliki interpersonal skill yang baik. Dalam keseharian responden bersikap murah hati, sangat simpatik dan mengenali perasaan rekan kerjanya, tapi tidak senang berkonflik untuk menjaga keharmonisan.

Untuk memaksimalkan kinerja responden dengan karakter pribadi ESFP, maka pimpinan melakukan coaching dengan merubah sikapnya yang suka terburuburu dalam mengambil keputusan menjadi lebih hati-hati dan penuh pertimbangan. Mengajak responden untuk lebih fokus pada tujuan dan tidak mudah berubah-ubah pada hal penting yang telah disepakati. Responden juga diajak untuk tidak selalu menyenangkan teman-temannya dan menyadarkan dia bahwa tidak semua otemannya bisa menyenangkan dia. Pimpinan memberikan motivasi agar responden siap menghadapi kritikan dan konflik dalam pekerjaan, tidak lari dari masalah dan memiliki rencana dalam penyelesaian masalah tersebut. Terakhir yang dilakukan pimpinan adalah memberikan partner alami responden dengan karyawan lain dalam tim yang berkarakter kepribadian ISTJ dan ISFJ, hasilnya responden sangat termotivasi dalam meningkatkan kinerjanya karena merasa memiliki rekan yang dia inginkan3.

\section{PEMBAHASAN:}

1. ENFJ adalah sosok yang suka menolong, memiliki em;pati tinggi, suka mendengarkan lawan bicara, dan memiliki tanggung jawab. Dia juga mudah menyesuaikan emosi, kebutuhan, dan motivasi dari orang lain. Sebagai seorang pemimpin ENFJ adalah motivator yang baik dan bersemangat, antusias, banyak ide dan kreatif. ENFJ juga merupakan pribadi yang cepat merespon kritikan dan pujian, suka sekali variasi dalam bekerja dan tantangan baru. Dia juga membutuhkan apresiasi dan penerimaan dari rekan kerjanya. Sebagai seorang yang memiliki karakter/kepribadian ENFJ, responden nomor 1 (satu) memang memperlihatkan karakter yang tidak bisa mengatakan "TIDAK", sangat permisive dan longgar dalam disiplin. Kadang membuat target pekerjaan terlambat karena terlalu banyak ide, kreatif mencari hal-hal baru dan tidak bisa mengambil keputusan tegas jika berbeda dengan anak-buah/atasan.

Responden lebih sering santai pada kondisi nyaman, berbincang berimajinasi dan menghabiskan waktu ditempat istirahat.

Melalui pendekatan pemberian motivasi serta adanya tugas yang menantang ide responden dalam bentuk individual task force, Manager mengembangkan karakter responden untuk lebih tegas, punya jadwal pencapaian target dan timeline, membangun sikap realistis, siap menghadapi konflik dan kritik. Manajer memberikan dua (2) individual task force yang berkaitan dengan individual task force responden 2(dua) dan 3 (tiga) sebagai anak buah. 
Sesuai target timeline yaitu dua (2) bulan, responden menampakan perubahan sesuai yang diinginkan dan mampu mencapai target task force. Keberhasilan responden mencapai target didukung juga oleh partner kerja yang cocok meskipun ada sedikit perbedaan, dimana ENFP yang memiliki sifat sama-sama ektrovet sering mengalami benturan pendapat dan ide. Namun dengan adanya perubahan responden untuk lebih mau mendengar, tegas, serta orientasi pada target, maka hubungan dengan ENFP membaik dan positif.

2. Kehangatan, antusiasme dan imaginatif adalah ciri khas sosok ENFP. Untuk itu responden sadar bahwa dalam bekerja selalu ada kemungkinan. Responden juga menunjukan kemampuan dalam memahami hubungan antara kejadian dan informasi dengan sangat mudah, responden sangat percaya diri dalam pekerjaan dengan melihat pola yang terjadi. Sosok pribadi responden membutuhkan pengakuan yang banyak dari rekan kerja, tetapi juga senang memberikan apresiasi dan dukungan kepada rekannya. Memiliki sifat yang spontan dan fleksibel adalah kebiasannya, kepandaiannya dalam berimprovisasi dan kefasihan lisannya menjadi andalan dalam menyelesaikan pekerjaan.

Sebagai sosok yang sangat ramah, penuh kehangatan, sangat enerjik, penuh optimisme, antusiasme, dan semangat yang tinggi membuat responden disenangi rekan kerja dan user didalam perusahaan. Dalam bekerja responden penuh dengan imajinasi, penuh ide, sangat kreatif dan inovatif dan aktif berkomunikasi dengan rekan kerja maupun user, senang bersosialisasi dan mampu memberikan situasi positif.

Melalui pengembangan dengan memberikan motivation achievement serta target pekerjaan dalam bentuk individual task force, responden selama dua (2) bulan memberikan hasil positif dengan menyelesaikan projek tepat waktu sesuai hasil yang diinginkan. Responden lebih siap menghadapi kritik dan konflik, membuat timeline schedule pekerjaan, lebih banyak berada dimeja kerja, dan fokus dalam setiap meeting serta diskusi dengan manajer.

3. ESFP adalah sosok yang ramah, bersahabat, dan menerima, mencintai kehidupan, orang, dan kenyamanan materi. Senang bekerja dengan orang lain dalam menyelesaikan sesuatu. menggunakan akal sehat dan pendekatan realistis dalam pekerjaan, dan menjadikan pekerjaan sebagai sebuah kesenangan. Fleksibel dan spontan, beradaptasi dengan mudah ke orangorang dan lingkungan baru. Cara belajar terbaik ESFP adalah dengan mencoba keterampilan baru bersama orang lain.

Sebagai pribadi ESFP responden memang sosok yang outgoing, easygoing, mudah berteman, bersahabat, sangat sosial, ramah, hangat, \& menyenangkan. Responden juga seorang yang Optimis, ceria, antusias, fun, menghibur, suka menjadi perhatian. Punya interpersonal skill yang baik, murah hati, mudah simpatik dan mengenali perasaan orang lain. Menghindari konflik dan menjaga keharmonisan suatu hubungan. Responden mengetahui apa yang terjadi di sekelilingnya dan ikut serta dalam mensukseskan kegiatan tersebut. Responden juga sangat baik dalam keadaan yang membutuhkan common sense, tindakan cepat dan ketrampilan praktis. 
Namun sosok responden sering ceroboh dan buru-buru dalam mengambil keputusan, tidak suka konsultasi dengan atasan karena dianggap ribet dan ridgid, berubah-ubah dalam penyelesaian masalah, possive terhadap pendirian, dan mengukur kerjasama atau teamwork dengan angka atau untung-rugi.

Manajer memahami bahwa responden ESFP perlu waktu lebih untuk melakukan coaching, assisting dan directing. Sehingga salah satu tugas responden ENFJ dari Manajer adalah melakukan coaching, assiting dan directing kepada responden ESFP. Dengan pertemuan terjadwal yang ditetapkan oleh ESFP, maka tiga responden punya jadwal tetap dalam koordinasi pekerjaan dan target task force. Sehingga segala hal yang akan diputuskan atau sudah diputuskan oleh responden ESFP dapat diketahui dan dianalisa bersama untuk mendapatkan tanggapan ataupun arahan agar sesuai target.

Hasilnya dalam dua bulan perencanaan waktu pencapaian target pekerjaan task force, ESFP memberikan hasil positif dengan memiliki kesabaran serta kehati-hatian dalam mengambil keputusan, selalu mengkoordinasikan dengan ENFJ sebelum mengambil keputusan. Responden juga lebih konsisten dalam pekerjaan, lebih siap dalam menghadapi konflik serta tidak perhitungan dalam teamwork.

\section{PENUTUP}

Karakter dalam bekerja sangat penting karena dapat mempengaruhi kinerja seseorang jika tidak tepat dalam menangani serta mengelolanya. Pimpinan sebagai pemegang kendali dalam sebuah organisasi memiliki kewajiban untuk mempertahankan kinerja terbaik tim-nya agar tercapai tujuan organisasi. Sehingga pimpinan sangat perlu memahami setiap karakter bawahannya agar bisa mengetahui cara pengembangan dan pengelolaanya.

Peran pimpinan dalam mengmbangkan serta mengelola karakter bawahan dapat dibantu oleh berbagai macam alat survey yang salah satunya adalah MBTI. Melalui peran survey MBTI diketahui karakter dominan seseorang apakah Instrovet atau Ekstrovet; Sensing atau Intuition; Thinking atau Feeling; Judging atau Perceiving. Dimana dengan diketahuinya berbagai karakter anak-buah, maka pimpinan akan memiliki data dalam proses pengembangan karakter pribadi anak buah yang ujungnya dapat membentuk karakter tim sesuai yang diinginkan dalam mencapai tujuan tim dan perusahaan.

Penulis menyampaikan banyak terimakasih kepada responden serta institusi CAP yang memperkenankan penulis melakukan survey MBTI sebagai salah satu media penilaian kinerja tim. Namun disadari bahwa hasil dari survey ini masih perlu dikembangkan lebih dalam seperti: melihat adanya kesulitan dalam melakukan pengembangan karakter yang negatif, menghitung basaran kenaikan kinerja yang didapatkan setelah program MBTI dan pengembangan karakter dilakukan, melihat sisi hubungan antara peningkatan kinerja setelah terjadi pengembangan karakter dengan peningkatan kinerja pimpinan, dan lain-lainnya. Karena keterbatasan yang dimiliki penulis, maka semua hal tersebut tidak bisa diselesaikan dalam satu makalah ini. Sehingga bisa dilanjutkan oleh penulis lainnya dimasa mendatang.

Atas kekurangan serta kelebihan yang ada, penulis menyampaikan banyak terimakasih atas terbitnya jurnal penuli ini kepada pihak Universitas Pamulang 
umumnya dan kepada pihak Program Pendidikan Ekonomi Fakultas Keguruan dan Ilmu Pendidikan khususnya.

\section{DAFTAR PUSTAKA}

Indotrading.com. 2010. Profile Perusahaan PT. Chandra Asri Petrochemical. Jakarta: Indotrading.com.

Ruby Hermanto. 2018. Managing Change - Prasetiya Mulya

Ruby Hermanto. 2018. Business Model Generation - Prasetiya Mulya

Ruby Hermanto. 2018. Delegaing - Prasetiya Mulya

Mawar Sheila. 2018. Motivating: Touch the Head and The Heart - Prasetiya Mulya Mawar Sheila. 2018. Giving Feedback \& Coaching for Performance - Prasetiya Mulya

Mawar Sheila. 2018. Directing - Prasetiya Mulya

Mawar Sheila. 2018. Leading Others Situational Leadership - Prasetiya Mulya Ruben Saragih. 2018. Self-Leadership: Personality Perspective - Prasetiya Mulya Prasetiya Mulya. 2018. Business Leadership Development Program - Prasetiya Mulya 